\title{
Can Enhanced Audit Quality Reduce Higher Real Earnings Management? — Evidence from China
}

\author{
Zhang Danyu \\ School of Business, East China University of Science Technology, Shanghai 200237, China \\ danyu0622@163.com
}

\begin{abstract}
In this paper we use data from listed companies in China to examine whether the firms with incentives to manage earnings upwards resort to real earnings management when facing higher audit quality. Based on our OSL model, we suggest that higher audit quality increases the level of real earnings management in the companies with upward incentives to management earnings. And the potential reason is the constraints on accrual earnings management at higher audit quality. Our results are helpful to regulate information disclosure. quality

Index Terms - real earnings management, incentives, audit
\end{abstract}

\section{Introduction}

The relationship between earnings management activities in listed companies and the quality of audit by the Certified Public Accountants has drawn great attention. Accrual earnings management (AEM) and real earnings management (REM) are two means to control earnings [1-2]. Prior literatures mainly focus on AEM and show that higher audit quality suppresses AEM [3-4]. However, recent studies strengthen the role of REM activity [5-6]. Due to its negative impact on future cash flow and long-term firm value, REM potentially exerts greater long-term costs on shareholder, which are driven by temporary price discounts or more aggressive credit policies that reduce margins on future sales, compared with AEM [5]. Moreover, Ref. [6] finds evidence that firms undertaking real earnings activities over-invest, which harms the long-term value of the company in turn.

Despite these negative effects, managers may still prefer REM, because it also draws less scrutiny from auditors and regulators [2] and doesn't influence their opinions or actions, as long as real earnings activities are disclosed properly in the financial statements [7].

Former studies concluded that higher audit quality serves well in constraining managers' accounting, such as AEM. For example, a model derived from Ref. [8] suggests that when accounting flexibility is reduced, companies tend to engage in REM. In addition, Ref. [1] believes the interchangeable roles between AEM and REM. However, it is still unknown whether Chinese managers will switch management style at higher audit quality. In this paper, we focus on companies with upward earnings management incentives and examine whether such firms resort to REM when the audit quality is higher. Further, we discuss whether its potential reason is improvement of audit quality associated with lower level of AEM. We find that because higher audit quality puts stronger constrains on AEM, managers will resort to REM instead.
This also supports the idea that improvement in audit quality is one of the reasons that a company chooses REM.

Our article makes two contributions. First, we reveals the evidence that companies choose REM to adapt stricter auditing, thus enriching literatures about earnings management incentives. Furthermore, we find the reason for this positive relation. Namely, higher audit quality constrains AEM and forces managers to take REM instead.

This paper is organized as follows. Section 2 develops our hypotheses. Section 3 is our research design. The fourth section describes our empirical results. And the last section is our conclusions and the suggestions.

\section{Hypothesis}

Previous studies have suggested that companies take the advantage of accrual activities to maximize their value and avoid negative consequences of contract default or routine business. Moreover, managers tend to tune profit higher by upwards earnings management, although this practice attracts more attention from auditors and brings more risks to the firm than downwards earnings management. REM and AEM serve similar functions in companies with upwards earnings management incentives. However, AEM has lower costs under normal conditions. This is because REM won't make firms involved in direct legal violation, as long as these firms disclose the real activities in financial statements properly [1-2], Thus, companies prefer REM under AEM constraints.

Ref. [9] finds out that the constraints on earnings management depend on audit quality, because higher audit quality is better at finding and reporting accounting errors and violations. Since big audit firms take high market shares, they maintain high audit quality in order to avoid the huge loss of market shares from audit failure, which exerts great constraints on Chinese listed companies [10-11].

Based on these studies, we propose our hypothesis H1:

H1: High audit quality can enhance REM among the companies with the incentives to manage earnings upwards.

\section{Research Design}

A. Sample

In this paper, we take the data of Chinese private enterprise listed in Shanghai Stock Exchange and Shenzhen Stock Exchange from 2006 to 2011 as our sample pool, including 9972 observations in total. All of the data are from CSMAR database and Wind database. Before running the regressions, we apply the following filtration rules. First, we 
drop 2202 incomplete observations. Second, we drop data of the 120 companies in financial industry because the relevant indicators are quite different from the other industries. Finally, we only keep companies with upward earnings management incentives, resulting in 3644 observations. We define a firm as with upward earnings management if it meets or just beats earnings benchmarks (zero earnings or previous year's earnings according to $[0,0.005]$ interval in Ref. [5]) or issues seasoned equities.

\section{B. Variables}

(1)REM: It includes three terms: manipulation of production, such as utilizing economies of scale; sales control, such as relaxing sales condition and credit; manipulation of discretionary expenditure, such as reducing spending on research and advertisement. We use models in Ref. [2, 5]. The calculated residuals are used as proxy variables for REM. First, we run the cross sectional regression for individual industry and year to estimate the normal values of the three terms; Second, we subtract the three values of a specific company in one year with the normal values of the corresponding industry and year and get the abnormal values; Finally, we converted the three terms into one REM indicator EMP.

(2) Audit quality is represented by yearly rankings provided by CICPA. We define Big10 as 1 if an audit firm ranks top 10, 0 otherwise.

(3) Control variables are defined as follows:

Lev $=\mathrm{a}$ firm's leverage, defined as debts deflated by prior period assets;

Roa $=$ a firm's return on assets, defined as the ratio of earnings before extraordinary items deflated by prior period assets;

Invst $=$ ratio of institute investors' share over total circulation market value;

MTB = a firm's market-to-book ratio;

State $=1$ if a firm's largest shareholder is the state and 0 otherwise;

Sep = degree of the separation of ownership and control;

Opn $=1$ if a firm gets standard audit opinion and 0 otherwise;

$\mathrm{MV}=\mathrm{A}$ firm's natural log of market value of equity.

\section{Models}

In order to test $\mathrm{H} 1$, we design the following model: $\mathrm{EMP}_{\mathrm{i}, \mathrm{t}}=\beta_{0}+\beta_{1} \operatorname{Big} 10_{\mathrm{i}, \mathrm{t}-1}+\beta_{2} \operatorname{Roa}_{\mathrm{i}, \mathrm{t}-1}+\beta_{3} \operatorname{Lev}_{\mathrm{i}, \mathrm{t}-1}+\beta_{4} \operatorname{MTB}_{\mathrm{i}, \mathrm{t}-1}+\beta_{5}$ $\mathrm{MV}_{\mathrm{i}, \mathrm{t}-1}+\beta 6$ Invsti $_{\mathrm{t}-1}+\beta_{7}$ Sep $_{\mathrm{i}, \mathrm{t}-1}+\beta_{8}$ State $_{\mathrm{i}, \mathrm{t}-1}+\beta_{9} \mathrm{Opn}_{\mathrm{i}, \mathrm{t}-1}+\sum \beta_{\mathrm{i}}$ Year $+\sum \beta_{\mathrm{j}}$ Inded $+\xi_{\mathrm{i}, \mathrm{t}}$

\section{Results}

\section{A. Descriptive Statistics}

TABLE I shows that among companies of upward earnings management, only $31.6 \%$ chose Big10 auditors and most of them received standard unqualified audit opinion. Moreover, based on the medians, more than $50 \%$ of the companies took positive earnings management.

\section{B. Empirical Findings}

TABLE shows that, in model (1), the coefficient of Big10 is significantly positive. This suggests that companies which have the incentives to manage earnings upwards and choose Big10 auditors have higher levels of REM. Thus, the result supports our hypothesis.

Next, we want to find out the reason of the above phenomenon. We hypothesize that higher quality of audit can lead to accrual constrains, which causes these firms resort to REM to manage earnings upwards. To testify this hypothesis, we build model (2) to do further examination. Here, we use the modified Jones model to measure the level of AEM. The regression results of model (2) show that Big10 has a significant negative effect on accrual earning management. This indicates that higher quality of auditing can inhibit upward accrual earnings activities in companies with upward manage earnings incentives. This may contribute to the relationship between REM and audit quality.

The results on control variables show that companies of better performance and higher value tend to make smaller positive earnings management while companies of better growth tend to make larger positive earnings management. Moreover, non-standard audit opinions make companies prone to larger positive AEM. But when a firm with positive earnings management incentives is given a non-standard audit opinion, it prefers greater REM. This may be due to the firm's intention to certify its good profitability to the market, which can turn the tables in terms of the non-standard opinion and lower the risk of next non-standard opinion from REM.

TABLE I Descriptive statistics

\begin{tabular}{|c|c|c|c|c|c|}
\hline Var & Mean & STD & Min & Med & Max \\
\hline DA & -0.009 & 0.181 & -0.621 & 0.064 & 0.716 \\
\hline EMP & 0.028 & 0.359 & -1.413 & 0.031 & 1.644 \\
\hline Big10 & 0.316 & 0.465 & 0 & 0 & 1 \\
\hline Roa & -0.009 & 0.095 & -0.351 & 0.010 & 0.265 \\
\hline Lev & 0.614 & 0.386 & 0.072 & 0.576 & 2.937 \\
\hline MTB & 3.709 & 4.455 & 0 & 2.294 & 27.390 \\
\hline MV & 21.530 & 0.998 & 19.700 & 1.440 & 2.210 \\
\hline Invst & 20.380 & 21.940 & 0 & 0 & 84.210 \\
\hline Sep & 5.444 & 7.589 & 0 & 0 & 28.530 \\
\hline State & 0.412 & 0.492 & 0 & 1 & 1 \\
\hline Opn & 0.869 & 0.338 & 0 & & 1 \\
\hline
\end{tabular}


TABLE II Regression results

\begin{tabular}{|c|c|c|c|c|}
\hline \multirow[t]{2}{*}{ Model } & \multicolumn{2}{|c|}{ (1) } & \multicolumn{2}{|c|}{$(2)$} \\
\hline & EMP & $\mathrm{t}$ & DA & $\mathrm{t}$ \\
\hline Const. & 1.004 & 1.30 & $0.288 * * *$ & 3.97 \\
\hline Big10 $0_{\mathrm{i}, \mathrm{t}-1}$ & $0.133^{* *}$ & 2.19 & $-0.010 *$ & -1.82 \\
\hline Roa $_{i, t-1}$ & $-1.072 * * *$ & -2.78 & $-0.145^{* * *}$ & -4.02 \\
\hline $\operatorname{Lev}_{\mathrm{i}, \mathrm{t}-1}$ & 0.016 & 0.19 & $0.081 * * *$ & 9.84 \\
\hline $\mathrm{MTB}_{\mathrm{i}, \mathrm{t}-1}$ & $0.012 *$ & 1.83 & $0.003 * * *$ & 4.97 \\
\hline $\mathrm{MV}_{\mathrm{i}, \mathrm{t}-1}$ & $-0.062 *$ & -1.68 & $-0.011 * * *$ & -3.15 \\
\hline Invst $_{i, t-1}$ & -0.000 & -0.06 & -0.000 & -0.93 \\
\hline Sep $_{i, t-1}$ & -0.000 & -0.12 & -0.000 & -0.34 \\
\hline State $_{i, t-1}$ & 0.063 & 1.01 & -0.007 & -1.16 \\
\hline Opn $_{i, t-1}$ & $0.216^{* *}$ & 2.14 & $-0.044 * * *$ & -4.64 \\
\hline Year & \multicolumn{4}{|c|}{ Control } \\
\hline Indcd & \multicolumn{4}{|c|}{ Control } \\
\hline $\mathrm{N}$ & \multicolumn{2}{|c|}{3644} & \multicolumn{2}{|c|}{3644} \\
\hline R_Square & \multicolumn{2}{|c|}{0.004} & \multicolumn{2}{|c|}{0.156} \\
\hline $\mathrm{F}$ & \multicolumn{2}{|c|}{2.072} & \multicolumn{2}{|c|}{48.930} \\
\hline
\end{tabular}

$t$ statistics in parentheses: ${ }^{*} p<0.1, * * p<0.05, * * * p<0.01$

\section{Conclusions}

This paper investigates whether the improvement in auditing quality can make a firm in favor of upward earnings management resort to real activities to manipulation profit. We find that these firms process a lower degree of AEM but a higher degree of REM when facing higher level of auditing quality. Our results indicate that Chinese listed companies prefer REM activities because of the constraints on accruals at higher level of audit quality. We suggest Chinese regulators take actions against such hidden manipulations.

\section{Acknowledgement}

This work is supported by National Nature Science Foundation of China (Grant No. 71172079).

\section{References}

[1] Zang, "Evidence on the Tradeoff between Real Manipulation and Accrual Manipulation", ProQuest, 2007

[2] Cohen, A. Dey, and T. Lys, "Real and accrual-based earnings management in the pre- and post-Sarbanes-Oxley periods", The Accounting Review, vol.83, no.3, pp. 757-787, May 2008.
[3] Johnson, Van E., Inder K. Khurana, and J. Kenneth, "Audit-Firm Tenure and the Quality of Financial Reports," Contemporary Accounting Research, vol. 19, no. 4, pp. 637-660, Winter 2002

[4] S. Balsam, J. Krishnan, and J. Yang. "Auditor industry specialization and earnings quality," Auditing: A Journal of Practice \& Theory, vol. 22, no. 2, pp. 71-97, September 2003.

[5] S. Roychowdhury, "Earnings management through real activities manipulation," Journal of Accounting and Economics, vol. 42, no. 3, pp. 335-370, December 2006.

[6] Cohen, and P. Zarowin, "Accrual-based and real earnings management activities around seasoned equity offerings," Journal of Accounting and Economics, vol. 50, no. 1, pp. 2-19, May 2010.

[7] Kim, L. Lei, and M. Pevzner, "Debt covenant slacks and real earnings management," Working paper, George Mason University Working Paper, November 2010.

[8] R. Ewert, and A. Wagenhofer, "Economic effects of tightening accounting standards to restrict earnings management," The Accounting Review, vol. 80, no. 4, pp. 1101-1124, October 2005.

[9] Becker, M. DeFond, J. Jiambalvo, and K. R. Subramanyam, "The effect of audit quality on earnings management," Contemporary Accounting Research, vol. 15, no. 1, pp. 1-24, Spring 1998.

[10] Cai, L. Yang, X. Chen, and Y. Chen, "The Empirical Analysis of the Factors Leading to the Audit Opinions," Finance and Economics, 14, January 2005.

[11] W. Yu, "Accounting-based earnings management and real activities manipulation," ProQuest, 2008 